Meta

Journal des traducteurs

Translators' Journal

\title{
Translator Education and Sustainability
}

\section{Mira Kim}

Volume 50, numéro 4, décembre 2005

Pour une traductologie proactive - Actes

For a Proactive Translatology — Proceedings

Por una traductología proactiva - Actas

URI : https://id.erudit.org/iderudit/019868ar

DOI : https://doi.org/10.7202/019868ar

Aller au sommaire du numéro

Éditeur(s)

Les Presses de l'Université de Montréal

ISSN

0026-0452 (imprimé)

1492-1421 (numérique)

Découvrir la revue

Citer cet article

Kim, M. (2005). Translator Education and Sustainability. Meta, 50(4).

https://doi.org/10.7202/019868ar
Résumé de l'article

Ce rapport décrit un projet de recherche active auquel j’ai participé: 'Action research for Change Towards Sustainability (ACTS) [Recherches actives pour un changement en éducation vers la durabilité] : Changement vers la durabilité dans les curricula et les compétences des diplômés en 2003-2004. La question de savoir comment incorporer la durabilité dans l'éducation des traducteurs a été explorée durant la recherche active en adoptant le constructivisme social comme approche pédagogique afin d'atteindre l'objectif de l'éducation pour la durabilité. La recherche s'effectue dans les salles de classe en utilisant la méthode de recherche active. L'étude a conclu qu'une approche pédagogique basée sur des projets collaboratifs est hautement efficace dans l'amélioration des compétences en traduction ainsi que les capacités génériques requises.
Ce document est protégé par la loi sur le droit d'auteur. L'utilisation des services d'Érudit (y compris la reproduction) est assujettie à sa politique d'utilisation que vous pouvez consulter en ligne.

https://apropos.erudit.org/fr/usagers/politique-dutilisation/ 


\title{
Translator Education and Sustainability
}

\author{
MIRA KIM \\ Macquarie University, Sydney, Australia \\ mira.kim@ling.mq.edu.au
}

\begin{abstract}
RÉSUMÉ
Ce rapport décrit un projet de recherche active auquel j'ai participé: 'Action research for Change Towards Sustainability (ACTS) [Recherches actives pour un changement en éducation vers la durabilité] : Changement vers la durabilité dans les curricula et les compétences des diplômés en 2003-2004. La question de savoir comment incorporer la durabilité dans l'éducation des traducteurs a été explorée durant la recherche active en adoptant le constructivisme social comme approche pédagogique afin d'atteindre l'objectif de l'éducation pour la durabilité. La recherche s'effectue dans les salles de classe en utilisant la méthode de recherche active. L'étude a conclu qu'une approche pédagogique basée sur des projets collaboratifs est hautement efficace dans l'amélioration des compétences en traduction ainsi que les capacités génériques requises.
\end{abstract}

\begin{abstract}
The paper presents a classroom-based action research project that I undertook as a participant in the action research project, Action research for Change Towards Sustainability (ACTS): Change in Curricula and Graduate Skills Towards Sustainability in 2003-2004. The classroom-based action research explored the question of how to incorporate sustainability in translator education. The research adopted social constructivism as a teaching approach to achieve the goal of education for sustainability. The whole process was studied by means of action research. The research found that collaborative project-based teaching is a highly efficacious method to improve translation skills and generic skills required for sustainability.
\end{abstract}

MOTS-CLÉS/KEYWORDS

translator education, social constructivism, sustainability, generic skills, collaborative project-based teaching, action research

\section{Introduction}

This paper presents action research that I undertook in 2003 and 2004 as a participant in a two-year pilot project called Action research for Change Towards Sustainability (ACTS): Change in Curricula and Graduate Skills Towards Sustainability. It was an inter-disciplinary project which was jointly funded by the Department of Environment and Heritage and Macquarie University in Australia. Ten action researchers, who were teaching postgraduate courses of law, environment, accounting or linguistics at different universities in Australia, participated in the project with individual research questions. This paper will start with the background of the ACTS project and move to the description of the research question, design and method, followed by lengthy discussion of findings and conclusion.

\section{Background of the ACTS pilot project}

The ACTS pilot project was commissioned as a result of an industry and university summit which was hosted by the National Environment Education Council and Macquarie University in November 2001. According to Tilbury and Cooke (2001: 50-52), the purpose of the summit was "to exchange views on the knowledge and skills required by business and industry to participate in the path towards sustainable development. During the summit, which was one in a series being held throughout Australia to help universities address new and emerging issues in the education for 
sustainability area, there was agreement that sustainability should not just be the concern of environment disciplines. Participants at the meeting identified the need of university graduates to have generic skills such as critical, creative and reflective thinking skills, problem-solving skills, communication skills, confidence to deal with uncertainty and awareness of sustainability to address the sustainability challenge. It was also highlighted that in spite of the need, many educators are grappling with the issue of how to integrate knowledge and skills for sustainability into their discipline areas."

In 2003, a series of workshops were facilitated by the ACTS Project Team for the participants to learn and discuss the principles of education for sustainability and action research as a new research paradigm. The workshop then moved on to more specific issues like data analysis methods for action research, identifying individuals' research questions, investigating our own understanding of sustainability within our own disciplines, research designs and schedules, and preparing ourselves for individual action research projects. In 2004, we launched our own projects and met in smaller groups. During the small "critical friends" group meetings we reported individual progress of our research and provided constructive feedback and encouragement to each other ${ }^{1}$.

\section{A role of translation for sustainability}

Sustainability is a highly important concept in the $21^{\text {st }}$ century that has been taken into serious consideration in international and domestic policy making processes in the environment and economic arenas. International conferences that deal with sustainability have been held around the world, for which conference interpreters are employed, and documents about sustainability have been translated in many different languages. This was the only possible link that I could think of between sustainability and translation at first. However, as I thought more about a role of translation for sustainability within the broad definition adopted for the ACTS project, namely "a better quality of life" at all levels starting from personal, community, social, national and up to global, I came to realize that translation (and interpreting) indeed plays a vital role in improving "quality of life" in many fields. This is because it makes information available in one language accessible to those who use other languages and helps communication between people with different languages and cultures.

However, there is an imbalance in what is translated simply because most of the translation jobs are commissioned by those who have economic and/or political power. In the Australian context, for example, multiculturalism is such an important issue that politicians never forget to mention it when they run for office. However, the federal, state or local government's budget that can be used for translation to promote multiculturalism does not seem to be sufficient. A primary school's Parents and Citizens' Association's president who asked for my help to translate its Constitution and By-laws said:

"The most up-front benefit is the access to high-level translation skills for no financial cost. A public school in Australia would never be given funds for such a luxury as communicating with the children's (non-English speaking background) parents. Telephone interpreters are available for one on one conversation between staff and parents. The one other means of affording these services would be to apply for a special one-off grant, a significant workload for non guaranteed outcome."

As a result, non-English speaking parents tend to be inactive and passive in participating in school and community events partly because they lack information about various events or understanding of community culture. Or they do not feel welcome.

\section{Research question, design and method}

Based on the imbalanced contribution of translation to sustainability and the need to integrate knowledge and generic skills for sustainability in teaching, I formulated a question for my project: 
How could I teach translation skills, as well as generic skills, addressing the issue of imbalanced contribution of translation to sustainability?

The research method of this study was classroom-based action research, which is "a form of systematic, naturalistic enquiry conducted within teachers' own classrooms with the objective of monitoring classroom practice, reflecting on this practice and bringing about any necessary changes highlighted in this process" (Burns 1998: 2). The course I chose for this study was an advanced translation course with 14 third semester students who had completed two translation courses as part of the requirements of the one and a half year MA program at Macquarie University. The advanced translation course (English-Korean) that covered 52 face-to-face contact hours during 13 weeks was divided into two classes, one mainly focusing on translation from English into Korean and the other mainly focusing on translation from Korean into English. As I taught translation from English into Korean, this study was conducted in half of the course that is 26 hours.

The course was designed with authentic translation tasks for real clients in such a way as to enhance students' translation skills and generic skills at the same time. Four translation projects were implemented throughout the semester. The following cycle was repeated in each project:

\section{Figure 1}

\section{Reflection}

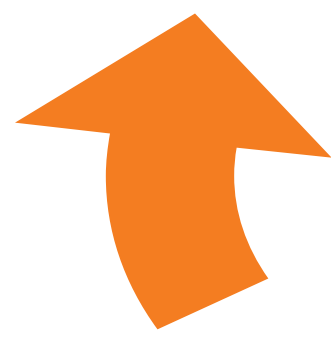

Data
collection

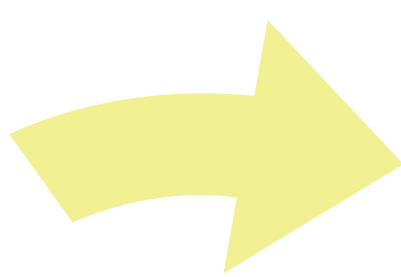

\section{Planning}

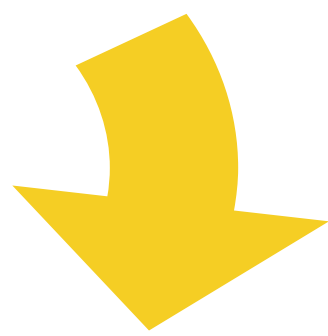

Action \& Observation

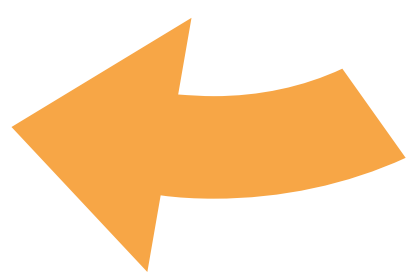

Planning: (Re)designing next project based on the reflection

Action \& observation: Running project

Data collection: Collecting data (students' journals, my journal and clients' feedback)

Reflection: Critically analysing data and reflecting on the whole process.

The main data for this study included students' journals, teacher's journal and clients' feedback. The students recorded their thoughts, feelings and learning points in their learning journals and submitted them after each project. They synthesized what they learned throughout the semester in their final end-of-semester essays. I kept my teaching/learning journals with observations and reflections on each class. At the end of each project, I invited the client to class so 
that they could give feedback to students in person. They expressed their appreciation and provided feedback to the students in person and/or in writing.

\section{Compatibility between social constructivism and sustainability}

The most significant benefit for me from participating in the inter-disciplinary ACTS project was that I was able to discover that issues discussed in one discipline may not be unique to the discipline but common across other disciplines. The gap between what universities teach and what industry needs graduates to have, which was pointed out at the industry-university summit in 2001, has been a concern in the translator education field and there have been efforts to address the gap by rethinking how to approach translator education. For instance, Kiraly (2000:15) contends that the conventional teacher-centred translation exercise class does not serve the needs that are required to educate professional translators in the $21^{\text {st }}$ century, such as development of professionalism. Being influenced by social constructivist ideas of Vygotsky, Bruffee, Rorty and Piaget (ibid:18), he alternatively proposes a collaborative learning class where the teacher creates a dynamic interactive learning environment with authentic translation tasks, which then empowers students to construct their own learning. Baer and Koby also find teaching methodology to be a possible reason for the gap between the tertiary education and industry:

[...] We may hope to better prepare students for the workplace by offering them appropriate tools, but if our teaching methodology is of the traditional kind - the performance magistrale described by Jean-Rene Ladmiral (1977) in which the master passes on his/her knowledge to a passive apprentice - we may fail to produce translators who are capable of the flexibility, teamwork and problem-solving that are essential for success in the contemporary language industry, not to mention the creativity and independent thinking that have always been the hallmark of the finest translators (2003: vii-viii).

Therefore, the social constructivist approach as the basis for my action research provided a significant guide to tackle the research question.

The recognition of how crucial the issues of sustainability and education for sustainability are, not only in environmental education disciplines but in higher education in general, provides legitimacy to the social constructivist approach. In other words, it justifies why it is important and worthwhile to pursue the alternative approach, even though it may require more time and effort to do so. Also there seems to be an international trend in universities towards education for sustainability. Tilbury and Cooke report:

Other presenters at the Summit spoke about the international declarations (e.g. Talloires and Lunenburg Declarations) and initiatives (e.g. University Leaders for a Sustainable Future) which committed universities to curriculum towards sustainability across all disciplines. Many universities around the world are currently rethinking their missions, restructuring their courses and operations and are looking for concrete ways to integrate sustainability across their campuses and faculties (2001: 51).

The following is my conceptual blue print that I drew from my understanding of the compatibility between social constructivism and sustainability. 
Figure 2

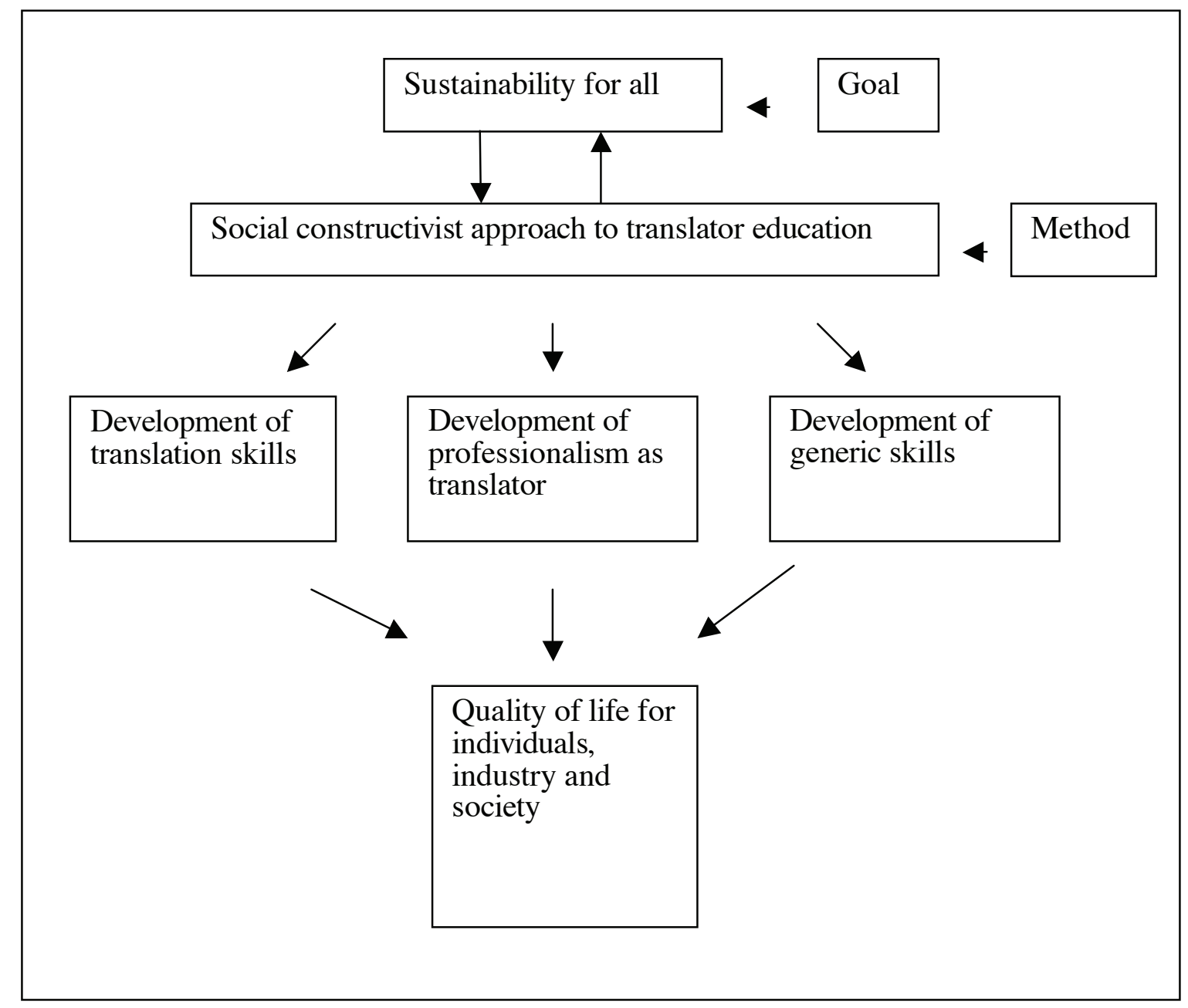

Within the context of my research design context, collaborative project-based translation teaching with authentic materials that could create real values for the society would benefit students as well as society. Students would be able to improve translation skills and also develop generic skills, which are called extra-linguistic skills in translator education. They then would be well prepared for the real professional community and have better employment opportunities because they are equipped with the skills that industry wants them to have. Business and industry would be able to improve productivity or profitability by employing such graduates. Non-profit organizations would benefit from students' voluntary translations, which are controlled in terms of quality by the teacher. The synergistic effects of this approach may include many more as yet unidentified benefits.

\section{Authentic collaborative translation projects}

The advanced translation course was run with four authentic translation projects. This section describes the four projects in detail: what texts were translated, how the projects were run, what the students learned, what I observed and how I interpreted the data. The analysis of the students' journals will be presented from two points of view, translation skills and generic skills. Also students' learning points which would have been hard to observe in a traditional teacher-centred translation exercise class will be highlighted. 


\section{What did we translate and for whom?}

Before the semester began, I contacted several organizations for whom we could provide translation services. Two immediate requests were made from the contacts. One came from a local primary school who asked for a translation of its Parents and Citizens' Association (P\&C) Constitution and By-laws. The purpose of the translation was to make non-English speaking background parents feel welcome at the school and encourage their participation in school events and P\&C activities in particular. The other request came from a non-profit Christian mission institute. They wanted to get Bible Skills Assessment Tests translated into Korean for Korean candidates who applied for mission work for the organization. They felt the Korean candidates had not been able to express their knowledge about the Bible and their beliefs in Christianity as much as they could have because of the language barrier.

I started the course with the first two tasks and invited the students to find translation jobs for which it would be worthwhile for us to provide free translation. However, no suggestions were made by the students. So we accepted a request by one of the ACTS Project Team to translate a Korean translation of Education for Intercultural Understanding in Australia back into English. She wanted to see if the translation conveyed the message that she wanted to get across. The last text was an unpublished, informal document prepared for the United Nations Decade of Education for Sustainable Development 2005-2014, which was prepared by the ACTS facilitator and others.

\section{How were the projects run?}

First, we allocated jobs and roles required to carry out the translation project. I encouraged the 14 students to take the initiative in nearly every activity including discussion, scheduling and terminology management and I limited my involvement to a minimum level as proofreader. Through discussion, it was decided that the project required a project leader (student), whose main responsibilities were communication between the translators and the client, scheduling a timetable and leading classroom discussions; a terminology manager (student), who provided an initial list of terminologies and updated the list, interacting with the translators as the project proceeded; a proofreader (teacher), who checked the quality of the translation; and an editor (student) who made sure that the final format of the translation was appropriate. The rest of the students translated their parts of the text in pairs outside class. In the following two weeks, we discussed issues and problems related to the text and the discussions were led by the student project leader. The final translation was handed in for proofreading. When we finished the translation for the local primary school, we invited the P\&C president to class so that she could explain how the translation was going to be used and what values the translation would create for the community.

The first project worked through trial and error, which was experienced by the students and myself. The followings are extracts from students' comments in their journals ${ }^{2}$ on the way the project was run:

\footnotetext{
"I learned what it is to work in a team but I think the job was too time-consuming. I met my group members three times to revise it again and again, which made me tired."

"I admit it was a good experience but don't think this kind of big project in which more than 10 people participate is needed more than once this semester ... because I guess we are all interested in improving individual translation skills."

"I think many students including myself still need to improve the comprehension skills... and I think we

still need to get feedback (from the teacher) on individual translations."

"We haven't done such a task before as we just translated for homework. So I think we need teacher's

help a bit."

"I think I learned a lot about translation project. However, I think it should have been better structured

as there were miscommunications and disagreements among group members or with the leaders."
} 
The students said in class discussion that communication, including giving and receiving feedback, was very difficult. They also mentioned that too many people were involved, the text was too difficult, the project was not well structured, roles and responsibilities were not clear and the teacher's help was not sufficient. There were other students who made positive comments or did not comment on the way it was run. But I thought those negative comments were very valid as I also felt it did not go very well, even though my observation about students' participation in the project was very positive. All the students participated very actively and in a lively way and they even suggested that they use a website, which they had set up for social interactions among themselves, to share ideas and ask questions after class. However, it took me about 10 hours to proofread their translation of the approximately 3500-word long text. That was much more time than I expected, after two weeks of class discussions and several student group meetings outside class for revision.

I carefully reflected on the students' feedback and redesigned the second project. Most importantly, I enhanced the scaffolding part, taking the role of project leader and facilitator myself and trying to model my own translation behaviour as I worked with small groups in class. I gave a more manageable task so that they did not have to meet outside class too often. This time the students were split into four groups. Each group consisted of three or four students and translated the same text. Therefore, by the end of the project, four different versions of translation were produced. In class, the students, in small groups, discussed translation issues and problems that they encountered when they were producing draft translations outside class. I moved from one group to another facilitating discussions and making suggestions for issues they raised. I particularly kept in mind that the students had difficulties in giving and receiving feedback on translations and tried to show good examples of constructive feedback while discussing specific translation issues. When further discussions were needed after class, some groups used email and others met once or twice. I proofread four versions of translation and chose the best one for the client.

General feedback on the project management was more positive than that on the first project:

"This project was easier than the last one. First of all, as we worked in smaller groups, it was easier to communicate smoothly. We discussed translation issues in class and also exchanged questions and suggestions via email. ... I think, the most important aspect of teamwork is whether or not each team member plays one's own roles with responsibility and how efficiently they express ideas and suggestions, which is an ability to give positive feedback. I evaluate this project as a success in both aspects."

"I think the confusion and inefficiency have reduced a lot because we were working in smaller groups."

The third project was run in the same way as the second project. From the third project, the students talked significantly less about the way the project was run but more about translation issues, both general and specific.

The fourth project was run in the same way as the second and third projects except that each student was required to submit their own version of translation. They split the text into three parts and translated one part each and discussed issues and questions in class as they had done in the previous projects. But this time each of them was requested to produce their own translation of the whole text reflecting on the discussions. Some students welcomed the method:

"I am very satisfied with the way the last project was run. I discussed issues and opinions together with my colleagues but could produce my own translation. I think this is an ideal way to combine benefits of group translation and individual translation."

\section{What did the students learn?}

The students mentioned a number of learning points in their journals, which were submitted at the end of each project, and their final essays, which summarized their learning experiences throughout the semester. They can be mainly categorized into two parts: translation skills, text-bound specific and general, and generic skills. 
When it comes to text-bound specific translation issues, the students compared different choices of translation and justified their own translation choices or why they thought one translation was better than the other. They applied their knowledge of translation theories and a translation error analysis system which I have suggested, based on systemic functional grammar-based text analysis (Kim 2005). Detailed examples of such issues will not be discussed here as it is not the main focus of this paper. However, what is worthwhile to mention is that their reasoning ability was enhanced to a large extent thanks to their group discussions in and outside class during which they had to verbalize reasons for their translation choices to each other. A number of students said they learned from each other as people's translation strategies were so different from one another other and they learned how the translation brief could actually impact on choices of translation at all levels. Some students commented:

"I'm always trying to learn more about translation by comparing my version with other people's versions. So translation projects have been helpful for me in various ways. I've newly realized various aspects (of translation) by reading others' translations. It is really incredible how differently people can translate even just one sentence!"

"This (second) project reminded me of the importance of background knowledge and translation brief. The fact that the tests were to be taken by potential missionaries determined my choices of terminologies and register."

One student said that the fourth project gave her an opportunity to feel the progress she had made in terms of translation skills:

"Producing my version of the last project, I felt proud of myself about not-insignificant progress I made (in translating) because I didn't get stuck to the source text structure any more but found myself enjoying more freedom in constructing the message that I got from the source text."

The students also mentioned professional aspects of translators. For instance, the third project provided an opportunity for them to reflect on their own attitudes about translation and translating. The students found the Korean translation so difficult to understand that there were several parts they could not understand even after several careful readings. After reading the translations that we did, the author of the original text said the translation did not convey the message that she had intended to deliver. Their experience of difficulty in understanding the translated text and the discussion with the client provided a very good opportunity for the students to reflect on their attitude to translation and the importance of translators being responsible. Some comments on this include:

"I had to read the Korean translation several times because I couldn't get the whole picture. As I was doing that, I came to think about my own attitude about translation especially from English into Korean. Even though I couldn't understand some parts of the text, I just translated them literally as I wanted to get it done by the due date. When I realized that I couldn't understand what I translated, I didn't bother to worry. When the client came to our class and said that the translation was written in a different way that she intended, I felt embarrassed thinking about my own irresponsible attitude about translation." "Maybe because we knew it was a translation from the beginning, we dealt with the translation very critically... I felt like I could translate it better than this. Then I thought that if I became a translator, I would get this kind of feedback on my translations and then realized how responsible work it is to translate. The realization made me think back my own attitude about translation. I asked myself if I had felt any responsibility about my translations and if there were any meanings of translation tasks more than just assignments. I felt embarrassed."

"My job for this project was translating my part of the text. I worked hard with my group as I didn't want to cause any problems because of me."

"I was given a job as a group leader for the first time. Even though I was a leader of a group of four people, I was surprised by the fact that this little job made me want to work responsibly." 
In terms of generic skills, a majority of the students mentioned communication skills. This was one of the reasons why some students suggested we do more individual translation exercises. They said:

"The most difficult part (in the first project) was communication."

"I felt very sorry to see my colleagues having difficulties in considering different opinions with an open mind. Maybe it was because it was our first real experience of translation project. Anyway I seriously realized by experience how important communication is among people involved."

Although many students said communication was difficult and realized how important it was after the first project, they did not actually mention what they could do to improve communication skills. This was one of the reasons why I continued to run the course with authentic projects. I did not want to deprive the students of a second opportunity to reflect on their experience and solve the problems that they were faced with and let them leave school with an impression that communication is a negative feature of group work. In fact, one student did appreciate the second opportunity:

"While the first project gave us an opportunity to understand problems that could occur in translation project, the second project gave us an opportunity to make full use of advantages of translation project. We all fulfilled our roles sincerely based on the well planned schedule and were able to improve translation quality through active discussions and close collaboration. And at the same time, we learned good attitudes for teamwork. I think we might have missed this important opportunity to learn valuable lessons from translation project if the translation course had been run in a way that students submit translations and the teacher corrects them. This opportunity also reminded me of the fact that I can get help from teacher but my colleagues can be my good teachers as well. I learned more from my colleagues than from dictionaries. Reviewing each other's translations, analyzing the source text together and trying to think more choices, I came to think translating is really fun."

Many students did make efforts to put into practice what they thought a good communicator should do while doing projects:

"As a group leader, I tried hard not to judge which translation is right or wrong but tried to create an atmosphere in which our group members can exchange opinions without hurting feelings.”

"I am now trying to be careful about language when I give feedback. For instance, instead of "this is wrong or right”, I say, “in my opinion, or my suggestion would be...” ... I think one of the highlights of the projects is training for efficient communication. A real professional translator should be able to listen carefully to other people when they express different opinions and should respect others' translations and should be humble when s/he comments on them, I believe."

"The most critical learning point for me through the projects is that we must bear in mind the purpose of giving and receiving feedback, which is to improve quality of translation and help each other improve. When it is forgotten, it is quite easy to try to show others that you know better than they do when you give feedback and it is also quite easy to try to over-defend yourself instead of accepting others' feedback constructively when you get feedback."

Other noteworthy comments by students after the last project are on critical thinking. Most of the students found it quite challenging to translate the last text. They learned from the discussion with the client that the text was not the final version but a draft which included a few mistakes and the text was written for the people who knew the field well. Therefore, it was written with an assumption that the reader would understand all the concepts presented in the paper. The students were surprised to hear from the client that the English source text did have some mistakes. They somehow believed that English source texts could not be wrong. When they did not understand English source texts, they would blame their lack of English competence. A few comments on that point: 


\begin{abstract}
"I now engage with source texts more actively and critically. I used to put absolute trust on English source texts written by native speakers and try to understand no matter what. In fact, it is not questionable that people do make mistakes when they write in their mother tongues. I wonder why I had not questioned English source texts but passively accepted them. But I don't think I am the only one who has such a problem. I guess native speakers are given every right to English unconditionally just because they are native speakers. ... A partial reason can be also found in our educational system in which those who well memorize what is written in books without critical thinking excel in multiple choice exams."

"The last text was the most difficult text among the four texts we translated this semester but I learned the most from the last project. First of all, I realized that the source text, which I nearly regarded as sacred, might include mistakes. It was very difficult because it was written for those who knew the field very well."
\end{abstract}

The students did not mention that they had developed reflective thinking skills by keeping their learning journals but many journal excerpts show that they reflected well on their learning experiences. As such, authentic project-based teaching, in conjunction with collaborative learning and reflective journal writing, provided an excellent opportunity for students to learn and improve their translation skills, translator attitudes and generic skills that are required for sustainability. One student said in her final essay:

"The experience of group projects was beneficial not only to developing my translation skills but also enhancing my generic skills. Since the translation course was proceeded focusing on cooperative learning instead of individual learning or teacher-students knowledge transmission, I could learn invaluable lessons about thinking skills and human relation skills...I used to think that translation activity is a lone(ly) joband more or less isolated job which does not require communication skills very much. However, through the team work, I could learn more about how to coordinate different opinions to improve the quality of translation." (Student's original journal)

Some students said they now understood why life-long learning is required for translators.

\title{
How did they contribute to sustainability?
}

The students had an opportunity to renew their perceptions about translation and translators after discussing with the real clients about values of the translations they produced. One student said after the first project:

"I had a kind of thought that translation is just a product that a translator produces for a living and is a bit isolated from society. I appreciate this opportunity to let us experience that it is deeply involved in society and furthermore it can make a positive contribution to a society... I won't forget the "thank you" afternoon tea." example:

They became more aware of sustainability issues by translating related documents. For

"Project 4 gave me an opportunity to know about the area that I had not been aware of. I didn't know that the United Nations is doing such work (taking initiatives for education for sustainable development) and I didn't know what it is."

It was not only the students but also the community who benefited from this teaching approach. It is very important to build collaborative partnerships in the process of moving towards sustainability (e.g. doing work for clients and then receiving feedback) as education for sustainability promotes teaching methods that connect students directly to action-taking, as well as making a contribution by developing skills for sustainability. Here is a quote from the P\&C president about a contribution that our translation has made to the community and a shift it has led to in social relations: 
"Having had access to the students has had subtle but important effects. It changed the focus from communication between the school administration and NESB (Non-English Speaking background) parents to between the parents; this has greatly assisted in promoting a sense of community and I hope decreased the isolation people might feel from the community due to language barriers. We have had a much largerproportion of NESB parents at many functions and a greater commitment to assistance around the school over the last year from this group. The university students' involvement has certainly legitimised our efforts and contributed to people's comfort with being involved."

\section{Conclusion}

The findings of the research have confirmed that the social constructivist approach is a highly efficacious teaching method to improve translation skills as well as generic skills required by society for sustainable development. In addition, it has shown that it helps the students realize the social value of translation, which will naturally lead to a positive self-image as professional translators. This teaching approach benefits not only the students but also the community by providing various community groups with translations that the students produce with guidance of the teacher. It can be said that this approach helps to establish collaborative relationships between universities and society, lessening the criticism that universities are ivory towers which have nothing to do with community. When we, translator educators, put in a little effort to find authentic translation tasks which could make a contribution to our society, we can create a win-win situation for both our students and society. In terms of quantity, what one translation class can produce might not be significant but it is still better than wasting our time and effort in translating texts that are not going to be used at all. If more and more classes would be run this way, the amount might not be negligible. Furthermore, if our students graduate not only with translation skills but also with critical, creative thinking skills and communication skills as responsible professionals, they will make invaluable contributions to our society in numerous ways.

\section{Acknowledgements}

This paper reports on research funded by the Department of Environment in collaboration with Macquarie University. The ACTS project, "Action Research for Change Towards Sustainability," is directed by Associate Professor Daniella Tilbury with Dimity Podger and Dr Anna Reid. Team members also included Professor Anne Burns, Kate Henderson and Dan Garlick.

\section{NOTES}

1. For details see the ACTS project final report, Tilbury, Podger and Reid (2004), which contains a detailed description of the ACTS project.

2. Most of the students' journals were written in Korean. Therefore excerpts of the journals in this paper are my translations unless they are noted as a student's original journal entry.

\section{REFERENCES}

BAER, B. J. and G. S. Koby (2003): "Introduction: Translation pedagogy: The other theory" in BAER, B. J. and G. KoBY (eds.) Beyond the IvoryTower, Amsterdam/Philadelphia, John Benjamins.

BuRns, A. (1998): "Critical questions in action research" in BuRns, A. and S. Hood (eds.) Teachers' Voices 3: Teaching Critical Literacy, Sydney, National Centre for English Language Teaching.

KIM, M. (forthcoming): "Translation error analysis: A systemic functional grammar approach" in KENNY, D. and K. RYOU (eds.) Selected Papers from the Inaugural Conference of the International Association for Translation and Intercultural Studies, Seoul, Centre for Translation and Intercultural Studies, Sookmyung Women's University. 
KIRAly, D. (2000): A Social Constructivist Approach to Translator Education: Empowerment from Theory to Practice, Manchester, St. Jerome.

TILBURY, D. and K. COOKE (2001): Building Capacity for a Sustainable Future: Meeting the Needs of Industry through Environmental Education, Sydney, Macquarie University.

TIlbury, D., D. PODGER, and A. REID (2004): Action research for Change Towards Sustainability: Change in Curricula and Graduate Skills Towards Sustainability, Final Report prepared for the Australian Government Department of the Environment and Heritage and Macquarie University, Sydney, Macquarie University. 